\title{
UNDERSTANDING HALAL FOOD SMES' BEHAVIOR INTENTION TOWARDS E-MONEY
}

\author{
Rina Sari Qurniawati ${ }^{1 *}$, Yulfan Arif Nurohman ${ }^{2}$ \\ *Corresponding Author \\ ${ }^{1}$ Department of Management, STIE AMA Salatiga, Jalan Diponegoro Nomor 39, Salatiga, Indonesia, \\ rinasari.qurniawati@stieama.ac.id \\ ${ }^{2}$ Department of Syariah Banking, IAIN Surakarta, Jalan Pandawa Kartasura, Sukoharjo, Indonesia, yulfanan@gmail.com
}

\begin{abstract}
This study investigates halal food SMEs intention on e-money use. Prior to the existence of electronic money (e-money), banking was a solution for small and medium enterprises (SMEs) in doing business and making transactions. Entering the era of the rise of fintech, banks are also competing in issuing their respective e-money. Sincethe lack of interest in halal culinary SMEs in using e-money, fintech companies need to be able to know and understand perceptions to increase interest in re-transacting using electronic money. However, there are a few studies discussing behavioral intention in this new area. Consequently, this study examines the factors that influence SMEs' intention to use e-money. A total of one hundred respondents are selected using a quantitative method as sources of data collection. The questionnaires are distributed using a purposive sampling method in Surakarta, Indonesia. The software used for analysis is SPSS 20. The results show that complexity, perceived behavioral control, trust and perceived risk significantly affect intention to use e-money. The implications of SMEs' behavior intention toward e-money are discussed.
\end{abstract}

Keywords: E-money, behavioral intention, SMEs

Received

August 25, 2020
Revised

September 25, 2020
Accepted

September 26, 2020
Published

September 30, 2020

\section{INTRODUCTION}

Transactions are activities that cannot be separated from human life. The use of money as a tool of payment has developed very rapidly. Money has evolved through different stages according to the time, place, and circumstances, from the earliest form of barter to the use of electronic money (e-money). This development cannot be separated from the rapid development of technology that makes money function as a payment tool more fast, efficient, and flexible. This has led to a change in the emergence of new innovations in using payment instruments.

The development of technology and finance in the era of globalization has created intense competition in the business world. Companies are required to have strategies and innovations to survive in the competition. Therefore, the company continues to innovate to meet the needs of society. To realize this, many companies turn to utilize information technology (IT) in business. Small and medium enterprises must also follow the development of IT so that their business can survive.

The problem is that now the world of financial technology (fintech) is becoming a competitive arena. Prior to the existence of fintech, banking was a solution for small and medium enterprises (SMEs) in doing business and making transactions. Entering the era of the rise of fintech, banks are also competing in issuing their respective e-money. Currently, SMEs continue to be targeted to use this technology. In other word, SMEs are being targeted to be digitized. Around 350 micro, small and medium enterprises (SMEs) from the former Surakarta residency took part in the Entrepreneurial Success training in the Digital Age which aims to introduce SMEs to various digital media as business instruments. 
The huge potential of the halal culinary market is of course very attractive to industry players, including Indonesian SMEs. Moreover, Indonesia is a country with the largest Muslim population in the world so that it is a potential market for halal products. With this opportunity, Indonesian SMEs should be able to become the major player in the domestic market. In the perspective of sharia, e-money law is halal. This law is based on the rule that every transaction in muamalah is basically allowed unless there is an argument that prohibits it, then at that time the law turns into haram. Now SMEs are in the era of the industrial revolution 4.0, which is the era of the use of technology and information so they have to start adjusting themselves ((Sari \& Santoso, 2019).

The presence of e-commerce has led to another innovation, namely the online payment system. Now there are several e-money-based online payment service providers, such as Ovo, Go-Pay, Paytren, and others. E-money provides advantages by prioritizing convenience, speed and efficiency compared to other non-cash payments. However, e-money is less popular because of the lack of public understanding. So that the belief that e-money can make life easier rather than difficult has not been achieved (Priambodo \& Prabawani, 2016)

The intention to perform behavior can occur if the individual has a positive evaluation of the performance behavior. On the other hand, the more an individual has a preferred attitude towards certain behaviors, the stronger the individual's intention to adopt that behavior. The issue of difficulties to access e-money mobile applications brings complexities (Khatimah \& Halim, 2014) Perceived behavioral control reflects an individual perception and confidence to perform the behavior in question (Ajzen, 2006) The significant and positive influence of perceived behavioral control already exist in some previous research in e-money (Khatimah \& Halim, 2014) Unless control over a behavior exists, intentions will not be sufficient as the predictor of the behavior. Consumers have shown reluctance to complete simple online purchases primarily due to risk concerns and, thus perceived risk is posited as a prominent barrier to consumer acceptance of online banking (Lee, 2009) Trust someone related to satisfaction, the more satisfied an individual, the higher the confidence level of a product (Oza et al., 2019)

Like most cunsumers, halal culinary SMEs in Surakarta are still getting used to transactions using cash. Consumers are still convenient to make transactions using cash when shopping at a restaurant so are the SMEs. Basically, if it is done with non-cash transactions, it will be faster without having to wait for the change. Bank Indonesia has attempted to increase e-money use.. However, there are still many people choosing to use physical money instead of non-cash money for transactions. The level of non-cash transactions in halal culinary SMEs in Surakarta is still low. According to the head of the representative office of Bank Indonesia Solo Bandoe Widiarto, the public is still convenient making transactions using cash compared to non-cash such as e-money.

Considering the phenomenon of the lack of interest of halal culinary SMEs in using emoney, fintech companies need to understand perceptions to increase interest in retransacting using e-money. This study intends to determine halal Culinary SMEs intention to use e-money. The variables focused in this study are complexity perceived behavioral control, trust and perceived risk. 


\section{LITERATURE REVIEW}

According to (Davis et al., 1989)behavior intention or use is defined as the level of how strong a person's desire or motivation to perform a certain behavior. Psychological factors that influence purchase decisions are motivation, perceptions, beliefs and attitudes. This factor can influence the decision making, giving rise to the intention of someone to do it. According to Sudarsono (1993) the factors that influence the emergence of intention are factors that are related to one's inner needs such as physical and psychological factors, social motive factors related to the need to get recognition and appreciation from the environment where they are located, and emotional factors that can measure intensity of people in paying attention to a certain desire or object. A person's intention to do something happens if the individual has a positive evaluation of a behavior. On the other hand, the better the attitude towards a certain behavior, the stronger the individual's intention to adopt that behavior.

Halal is an Arabic term of "permissible" or "lawful". In English, it most frequently refers to food that is permissible according to Islamic laws as stated in Quran. Therefore, halal is actually about everything from the food we consume to the businesses transactions that are performed in our daily lives (Omar et al., 2008) Halal and non-Halal covers all spectrums of Muslim life, not limited to foods and drinks only, but also for safety, animal welfare, social justice and sustainable environment.

The purchase intention relationship is a consumer's plan to buy a certain product and how many units of the product are needed in a certain period. It can be said that buying interest is a mental statement from the consumer that reflects the purchase plan for a particular product. Behavioral intention has been widely discussed in previous studies that discuss payment systems and other technology acceptance. However, the discussion of behavioral intention on mobile e-money has not much been found in many previous studies especially in the SMEs area.

Electronic money (e-money) according to Bank Indonesia Regulation No. 20/6 / PBI / 2018 concerning Electronic Money is a payment instrument that fulfills the following elements, first, it is issued on the basis of the value of money that is previously determined by the holder to the issuer. Second, values are stored electronically in a medium such as a server or chip. Third, the value of electronic money deposited by the holder and managed by the issuer is not referred to in the law governing banking (Martowardojo, 2018). Bank for International Settlements (1996) defines electronic money as a product of stored-value or prepaid where a certain amount of money is stored in an electronic medium that is owned by a person.

E-money has several benefits compared to cash or other non-cash payment instruments, first it is faster and more convenient than cash, especially for transactions of small value, because customers do not need to provide an exact amount of money for a transaction or have to keep the change. In Islam, the law of change is described in surah An-Nisa verse 29, Allah Say "O you who have believed, do not consume one another's wealth unjustly but only [in lawful] business by mutual consent. And do not kill yourselves [or one another]. Indeed, Allah is to you ever Merciful". Muslim entrepreneurs who use e-money in transactions can apply Islamic practices in accordance with the Al-Quran. 
In addition, errors in calculating change from a transaction do not occur when using emoney. The time required to complete a transaction with e-money is much shorter than a transaction with a credit or debit card, because it does not require an on-line authorization, signature or PIN. In addition, with off-line transactions, communication costs can be reduced. The Electronic Values can be topped up into an e-money card through various means provided by issuers (Hidayati, et al, 2006).

Complexity refers to the extent to which an innovation is still considered difficult to use and understand (Taylor \& Todd, 1995)This is in line with the consequences of perceived usefulness (Davis et al., 1989). Complexity is a corollary of the "ease of use" variable in Technology Acceptance Model or TAM (Davis et al., 1989; Taylor \& Todd, 1995). This shows the extent to which an innovation is seemed difficult for its users to understand, study, or operate. Besides, being an innovative technology that is considered easier to use and less complex has a higher likelihood of being accepted and used by potential users. Therefore, complexity is expected to have a negative relationship with the intention to use e-money. Complexity (and consequently, ease of use) has been found to be an important factor in technology adoption decisions (Davis et al., 1989)

H1: complexity negatively affects the intention to use e-money for halal food SMEs in Surakarta (Tonglet et al., 2004)

Theory of Planned Behavior provides a systematic framework for investigating what factors influence a person to do something that affects one's behavior and this theory has been widely applied in various fields of behavioral sciences (Tonglet et al., 2004). Based on the TPB model, a person's behavior is a function of intention, in which one's intention is formed from the presence of attitudes, subjective norms, and perceived behavioral control

Perceived Behavioral Control (PBC) in Theory of Planned Behavior as an estimate of the degree to which a person has control over whether he or she is capable of performing the behavior (Terry \& O'Leary, 1995). This arises from the level of subjective control over a behavioral performance when someone assesses the ease or difficulty of performing the behavior (Ajzen, 2006). PBC which describes the user's perception if they have the necessary resources such as time and money (external factors), self-confidence abilities, and selfefficacy (internal factors) to successfully perform a behavior.

In general, PBC plays a vital role in IT adoption and the role of PBC on intention has been confirmed by early seminal work (Terry \& O'Leary, 1995). Empirical studies have found an association between PBC and intentions (e.e Lau, 2002; Shih \& Fang, 2004) In the context of mobile services, the study also verifies that perceived behavioral control positively influence behavioral intentions (Quan et al., 2010; Shin et al., 2009).

\section{H2: Perceived behavioral control positively affect the intention to use e-money for halal food SMEs in Surakarta}

According to Jogiyanto (2007), trust represents cognitive structures that are developed individually after collecting, processing, and synthesizing information, and including individual assessments of various related results. Trust becomes the basis for transactions for sellers and buyers that make consumers have high hopes to be satisfied with the exchange relationship. Trust in electronic e-money determines the consumer's decision to engage with e-commerce business providers. With regard to online crime, the future of e-commerce 
depends on consumer confidence in a web retailer and in internet technology (Widyaningsih, 2019).

According to the experts, it can be concluded that trust is a psychological condition for accepting a relationship after the parties collect, process, and synthesize information. Where the relationship is carried out in an uncertain environment and is influenced by expectations between parties. With this belief, a relationship between parties will maintain interests, commitment, and provide services and benefits to others. Trust is needed by the use of information technology to reduce social complexity in dealing with unwanted possibilities. Therefore, trust must be embedded in individuals to choose an electronic money product.

\section{H3: Trust positively affect the intention to use e-money for halal food SMEs in Surakarta}

Perceived risk is a customer's perceptions of uncertainty and undesirable consequences in carrying out activities (Dowling \& Staelin, 1994) According to Featherman \& Pavlou (2003), Risk perception is a perception of uncertainty and undesirable consequences of using a product or service (Rustanto \& Kartini, 2019). Lee (2009) found there are five of perceived risks when the customers perform the online transactions. They have to accept uncertainty risks or called perceived risks such as security/privacy risk, time/convenience risk, financial risk, social risk, and performance loss that still need to investigate further when customers use the e-money.

According to Leerapong \& Mardjo (2013) perceived risk is a negative consequence that consumers want to avoid when buying or using a product. The possible negative consequences or risks are manifold. A physical risk such as accidents caused by the engine of the product being purchased have been damaged is one example. Bauer (1960) defines perceived risk as uncertainty about the possible consequences of using a product or service. This implies that the level of risk a person feels and their own tolerance for risk taking are factors that influence a person's attitude in making decisions to do or not to carry out certain behaviors.

Security, privacy and safety risks that are issued can affect the customer's perception of an activity. This shows that the level of security has an effect when using e-money for transactions. Security related to electronic money is that users feel protected either from issuance errors that result in electronic money cards that cannot be used, or feel protected from damage (Ramadhan, 2016). Perception plays a strong role in reducing consumer interest in taking part in transaction activities so that perceived risk may have a negative effect on conducting a transaction. In Priambodo \& Prabawani (2016) perceived risk has a negative and significant effect on the interest in using electronic money.

H4: Perceived risk negatively affect the intention to use e-money for halal food SMEs in Surakarta.

\section{METHOD}

This research is an explanatory research, which is a type of research that aims to provide an overview of the research subject based on variable data obtained from the subject under study and is intended for hypothesis testing (Azwar, 2000: 56). Halal culinary in this study refers to food sellers who sell halal food whose characteristics have been described in the Al- 
Quran. The populations in this study are 1,729 halal culinary SMEs in Surakarta. The sampling method in this research is non-probability sampling with purposive samping technique. Where the requirements of respondents in this study are halal culinary SMEs who have used e-money as payment tool. The sample size to be used is determined using the Slovin formula with the results of 100 respondents.

\section{Research Instrument}

Questionnaire is used as an instrument of the study that examines all of variables using a five point likert scale (from strongly agree to strongly disagree). The operational definition is the translation of a research variable into more detailed indicators so that the existing variables can be measured. The operational definition of this research is as followed:

Table 1: Operational Translation

\begin{tabular}{|c|c|}
\hline Variable & Indicator \\
\hline $\begin{array}{l}\text { Intention to use E- } \\
\text { Money (Y) }\end{array}$ & $\begin{array}{l}\text { I. I will definitively keep using advanced mobile services on e-money transaction } \\
\text { payment. } \\
\text { II. I expect to use advanced mobile services on e-money transaction payment in the } \\
\text { future as well } \\
\text { III. I expect that advanced mobile services on e-money transaction payment will } \\
\text { make everything easier in the future } \\
\text { IV. I think others should use advanced mobile services as well on e-money } \\
\text { transaction payment } \\
\text { V. The use of e-money is very practical, saves time and effort, and provides future } \\
\text { VI. I am interested in using e-money because there are many advantages in business }\end{array}$ \\
\hline Complexity & $\begin{array}{l}\text { i. Learning to operate e-Money in mobile phone would be easy for me } \\
\text { ii. I would find it easy to get e-Money in mobile phone to do what I want it to do } \\
\text { iii. My interaction with e-Money in mobile phone would be clear and understandable } \\
\text { iv. I would find e-Money in mobile phone to be flexible to interact with }\end{array}$ \\
\hline $\begin{array}{l}\text { Perceived Behavioral } \\
\text { Control }\end{array}$ & $\begin{array}{l}\text { i. I will be able to use the e-money in my mobile so well in payment transaction } \\
\text { ii. Using e-money in mobile is entirely within my control } \\
\text { iii. I have the resources, knowledge, and ability to use e-money in my mobile }\end{array}$ \\
\hline Trust & $\begin{array}{l}\text { i. I feel safe when transacting on the internet using e-money } \\
\text { ii. E-money will not be damaged like physical money } \\
\text { iii. } \\
\text { iv. I -money selected in my business transaction has already a license } \\
\text { v. I believe there are many benefits provided in transactions using e-money }\end{array}$ \\
\hline Perceived Risk & $\begin{aligned} \text { i. } & \text { Use of e-money to avoid payment errors } \\
\text { ii. } & \text { Use of electronic money to minimize crime } \\
\text { iii. } & \text { The use of electronic money can minimize losses because of disasters such as } \\
& \text { floods, fires, etc. } \\
\text { iv. } & \text { E-money carries a low risk } \\
\text { v. } & \text { E-money is easy to store without fear of loss }\end{aligned}$ \\
\hline
\end{tabular}

In analyzing the data, researchers used multiple regression analysis. Multiple regression analysis formulation. Is as follows:

$\mathrm{Y}=\mathrm{a}-\mathrm{b} 1 \mathrm{X} 1+\mathrm{b} 2 \mathrm{X} 2+\mathrm{b} 3 \mathrm{X} 3-\mathrm{b} 4 \mathrm{X} 4+\mathrm{ei}$

Information :

$\mathrm{Y}=$ Intention to use E- Money (Y)

$\mathrm{a}=$ Constant 
$\mathrm{X} 1$ = Complexity

$\mathrm{X} 2$ = Perceived Behavioral Control

$\mathrm{X} 3=$ Trust

$\mathrm{X} 4$ = Perceived Risk

b1, b2, b3, b4 = Regression Coefficient

ei $=$ error

\section{RESULT}

\section{Descriptive Statistics}

A total of 100 questionnaires were distributed to halal culinary SMEs in Surakarta. Out of 100 questionnaires, 95 questionnaires were returned. The respondents who responded to this study are 53 male representing $55.8 \%$ and 42 female representing $44.2 \%$ of the total respondent. The respondents who responded to this study are 25 respondents from age $>25$ representing 26.3\%, 30 respondents from age 26-35=representing 31.6\%, 32 respondents from age 36-45 representing 33.7\%, 2 respondents from age 46-55 representing 2.1\%, and 6 respondents from age $>56$ representing $6.3 \%$ of the total respondent. The highest respondent income per month is less than IDR 5.000.000 (55.8\%).

Table 2: Sample Demographics

\begin{tabular}{|l|l|l|c|}
\hline \multicolumn{1}{|c|}{ Measure } & \multicolumn{1}{|c|}{ Item } & Frequency & Percentage (\%) \\
\hline Gender & Male & 53 & 55.8 \\
& Female & 42 & 44.2 \\
\hline Age & $<25$ & 25 & 26.3 \\
& $26-35$ & 30 & 31.6 \\
& $36-45$ & 32 & 33.7 \\
& $46-55$ & 2 & 2.1 \\
& $>56$ & 6 & 6.3 \\
\hline Income per month & IDR 5.00.000 & 48 & 50.5 \\
& IDR 5.000.000-IDR 15.000.000 & 32 & 33.7 \\
& IDR 15.000.000-IDR 50.000.000 & 12 & 12.6 \\
& IDR 50.000.000 - IDR 75.000.000 & 1 & 1.1 \\
& IDR 75.000.000 - IDR 100.000.000 & 1 & 1.1 \\
& $>$ IDR 100.000.000 & 1 & 1.1 \\
\hline
\end{tabular}

Source: output SPSS 2020

For the validity testing, we use Confirmatory Factor Analysis (CFA). CFA can test whether a construct has unidimensional or whether the indicators used can confirm a construct or a variable. The indicators of each construct that have a significant loading factor indicate that the indicator is a unit of measuring tool that measures the same construct and can predict the constructs that should be predicted . According to Hair et al., (1998), The validity test is carried out using confirmatory factor analysis with SPSS software. 
Table 3: Validity Test

\begin{tabular}{|c|c|c|c|c|c|}
\hline Variable & 1 & 2 & 3 & 4 & 5 \\
\hline IUEM1 & & & & 0.714 & \\
\hline IUEM2 & & & & 0.756 & \\
\hline IUEM3 & & & & 0.602 & \\
\hline IUEM4 & & & & 0.708 & \\
\hline IUEM5 & & & & 0.726 & \\
\hline IUEM6 & & & & 0.777 & \\
\hline CPXY1 & & 0,765 & & & \\
\hline CPXY2 & & 0.872 & & & \\
\hline CPXY3 & & 0.853 & & & \\
\hline CPXY4 & & 0.807 & & & \\
\hline PCB1 & 0.662 & & & & \\
\hline PCB1 & 0.806 & & & & \\
\hline PCB1 & 0.797 & & & & \\
\hline TRUST1 & & & & & 0.546 \\
\hline TRUST2 & & & & & 0.666 \\
\hline TRUST3 & & & & & 0.652 \\
\hline TRUST4 & & & & & 0.667 \\
\hline TRUST5 & & & & & 0.704 \\
\hline RISK1 & & & 0.652 & & \\
\hline RISK2 & & & 0.508 & & \\
\hline RISK3 & & & 0.801 & & \\
\hline RISK4 & & & 0.741 & & \\
\hline RISK5 & & & 0.704 & & \\
\hline
\end{tabular}

Source: output SPSS 2020

Furthermore, the reliability testing of each construct is carried out using Cronbach's coefficient. All the variables in this study, namely, Intention to use E-Money, Complexity, Perceived Behavioral Control, Trust, Perceived Risk, show a result above 0.6. This indicates that all respondents answered all the questions in the questionnaire consistently. 
Table 4: Reliability Test

No

Variable
Corrected item-Total Correlation
Cronbach's Alpha

1 Intention to use E-Money (IUEM)

0.898 Reliable

2 Complexity (CPXY)

0.933 Reliable

3 Perceived Behavioral Control (PCB)

0.874 Reliable

4 Trust

0.871 Reliable

5 Perceived Risk

0.788 Reliable

Source: output SPSS 2020

The classical assumption test has been accomplished and normality, multicollinearity and heteroscedasticity tests have been examined by using SPSS 23. The result of the normality test using Kolmogorov Smirnov has indicated that the value of asymptotic significance at 0.2 is higher than 0.05 . Thus it can be concluded that the residual data has a normal distribution. According to Sekaran \& Bougie (2016), one of the simple measures for identifying multicollinearity is to use tolerance value and variance inflation factor (VIF) or the inverse of tolerance value. In order to conduct the heteroscedasticity test, Glitter test is performed by regressing the residual absolute value against the independent variable. If the significance value is more than 0.05 , then the regression model is free of heteroscedasticity. The result of heteroscedasticity test using Glitter test, show that all independent variables had a significant value higher than 0.05. Thus, the regression model is free of heteroscedasticity tendency. A regression model that is free of multicollinearity is the model which has tolerance value more than 0.01 or has a variance inflation factor (VIF) less than 10 . All variables in this study have the tolerance value more than 0.1 and the variance inflation factor (VIF) value is less than 10. Thus, it can be concluded that the model is free from multicollinearity.

In this section, the multiple regression model is applied to test the independent variables, that is Complexity, Perceived Behavioral Control, Trust and perceived risk on the dependent variable, Intention to use E-Money. Multiple regression model use SPSS 18 for Windows and regression use the enter method. The enter method is a method that includes all the independent variables into the regression equation. Intention to use E-Money scores was regressed on four independent variables. Intention to use E-Money is indicated by the formulate $\mathrm{y}=3.739-0.290$ (Complexity) +0.335 (Perceived Behavioral Control) +0.675 (Trust) -0.228 (Perceived Risk). The $\mathrm{R}$ value of independent variables on the dependent variable (0.794) shows that Intention to use E-Money is strongly influenced by the factors; the value of adjusted R2 (0.630) is high according to Cohen's (1988) benchmarks and suggests that they account for $63 \%$ of the variability in Intention to use E-Money. The shrinkage between the R2 and the adjusted R2 values is 0.16 , indicating that if the model was derived from the population rather than the sample, it would account for approximately $16 \%$ less variance in the outcome. The $\mathrm{F}$ ratio value $(38.3)$ is significant $(\mathrm{p}=0.000<0.005)$ indicating that the beta coefficients can be used to explain each of the factors' relative contribution to the variance in Intention to use E-Money. 
Table 5: Regression Model

\begin{tabular}{|l|l|l|l|r|r|}
\hline \multirow{2}{*}{ Dependent Variable } & \multicolumn{2}{|c|}{ Unstandardized coefficients } & Standardized coefficients & \multirow{2}{*}{ t } & \multirow{2}{*}{ Sig } \\
\cline { 2 - 3 } & B & Std. Error & & & \\
\hline Constant & 3.739 & 2.008 & & 1.862 & .066 \\
\hline Complexity & -.290 & .132 & -.154 & -2.199 & .030 \\
\hline Perceived Behavioral Control & .335 & .100 & .256 & 3.343 & .001 \\
\hline Trust & .675 & .118 & .554 & 5.701 & .000 \\
\hline Perceived Risk & -.228 & .113 & -.178 & -2.009 & .048 \\
\hline
\end{tabular}

$\left(\mathrm{R}=.794, \mathrm{R}^{2}=.630, \mathrm{~F}=38.320, \mathrm{p}=.000\right)$

\section{DISCUSSION}

From several factors that influence intention of halal food SMEs to use e-money, complexity is proven to have negative effect. Complexity with perceived ease of use is part of the effort expectancy which is the degree of ease associated with using the system (Khatimah $\&$ Halim, 2014). The result of this study also supports hypothesis 1 that complexity $(\beta=-$ $0.290 * * * \mathrm{t}=-2.199, \mathrm{p}>0.05)$ has a significant negative to Intention to use E-Money. According to Taylor \& Todd (1995) complexity is significantly negative related to attitude on behavioral intention. Complexity is significantly negative correlated with attitude of using emoney system (Khatimah \& Halim, 2014)There are still many SME owners of halal food who are over 35 years old facing complexity to make some innovations or new ideas and finding difficulties to use e-money.

This study hypothesizes perceived behavioral control positively affects Intention to use E-Money. As hypothesized, perceived behavioral control $\left(\beta=0.335^{* * *}, \mathrm{t}=3.343, \mathrm{p}<0.01\right)$ have a positive significant effect on Intention to use E-Money. Therefore, the result of this study supports the hypothesis 2. Ajzen (1991) concludes that perceived control over the behavior usually predict behavioral intention with a high degree of accuracy. Perceived behavioral control play important roles in determining the intention to use e-coupons (Kang et al., 2006). The theory of planned behaviour proposes that Perceived Behavioral Control, along with behavioural intention, might be a good predictor of the achievements of an individual in a specific field (DINC \& BUDIC, 2016).

According to $\mathrm{Ba}$ and Pavlou (2002) trust is an assessment of a person's relationship with other people who will carry out certain transactions in accordance with an expected environment with full of uncertainty for program recipients in the organizational decision process. As hypothesized, the results indicate that trust $(B=0.383271 * * *, t=7.227, p<0.01)$ have a positive significant effect on Intention to use E-Money. Hence, hypothesis 3 is supported. Based on the facts, SMEs who believe in using electronic money will increasingly use this electronic money. The results of the study are in line with the results obtained by Pratama and Suputra (2019) which prove that trust has a positive effect on the intention to use electronic money.

Perceived risk is a customer's perceptions of uncertainty and undesirable consequences in carrying out activities (Dowling \& Staelin, 1994). According to Khatimah \& Halim (2014), Perceived risk is uncertainty and unpredictable effects to use the system when the consumers use it. The result of this study also supports hypothesis 4 that perceived risk ( $B$ $\left.=-0.0228^{* *}, \mathrm{t}=-2.009, \mathrm{p}>0.05\right)$ has negative and significant effect to the intention to use emoney. According to Leerapong \& Mardjo (2013) perceived risk is a negative consequence 
that consumers want to avoid when buying or using a product. The use of e-money by halal food SMEs can avoid the risks that may occur when using cash. Currently, the risk of loss due to the use of e-money has been reduced so that many SMEs use it. This finding has also been supported by other studies (e.g. Lee, 2009; Tan and Teo,2000; Yousafzai, Pallister and Foxall, 2003).

\section{CONCLUSION}

In general, the findings of factors and their attributes from this study are in line with the findings in the literature. Four independent variables are proven to have an effect on the intention to use electronic money as a payment tool. In understanding the nature of the SMEs' intention to use e-money, this study is expected to contribute to the e-money mobile knowledge in several ways. The information is expected to help in explaining the underlying theory of e-money and consumer behavior.

Firstly, this study gives contributions to enhance the specific behavioral theory by relating it to the intention to use e-money mobile which is still limited in Indonesia, since most explanations in other studies involve general theory such as e-commerce, e-banking, and other social networking. Besides, this study also contributes to literature review related to SMEs' intention to use e-money and mobile transactions in Indonesia.

Secondly, this study helps academics who are interested in the intention to use the topic, since there are only a few similar studies, more specifically the application of e-money by SMEs. With so many SMEs in Indonesia, the use of e-money can be used for business development.

\section{Limitation}

Firstly, the research only used 4 variables (complexity, perceived behavioral control, trust and perceived risk). So there are still other independent variables that might influence the intention to use electronic money as a payment tool for SMEs, especially those engaged in halal food. Secondly, this research was conducted in a limited time so that the results of the study were limited to the research location which was only conducted in the Surakarta area.

\section{REFERENCES}

Alarussi , A. S., \& Alhaderi, S. M. (2018). Factors Affecting Profitability in Malaysia. Journal of Economis Studies, 442-458.

Anshori, M., \& Iswati, S. (2019). Quantitative Research Methodology. Surabaya: Airlangga University Press.

Azwar. (2016). Allocative role of the goverment through goods / services and its effect on the economy Indonesia. study of financial economics , 149-167.

Gujarati D. (2004). Basic Econometrics, 4th Edition. New York : McGraw-Hill.

Harapah, P. (2009). Econometrics Module Tutorial . Yogyakarta: UGM.

Harianingrum, S., Nafik H., M., Fauzi, Q., Afifa, F. U., \& Laila, N. (2019). The effect of Goverment Expenditure on Islamic Human Development Index. Opcion, 685-703.

Hassan, M. K., Paltrinieri, A., Dreassi, A., Miani, S., \& Sclip, A. (2018). The determinants of co-movement dynamics between sukuk and conventional bonds. The Quarterly Review of Economics and Finance, 73-84.

Huda, N. (2012). Islamic Public Finance Approach Theoretical and Historical. Jakarta: KENCANA. 
Iqbal, Z., \& Mirakhor, A. (2007). An Introduction to Islamic Finance: Theory and Practice. Hoboken, NJ: Wiley Finance Editions, John Wiley and Sons.

Izhar, H., \& Asutay, M. (2007). Estimating the profitability of islamic banking: evidence from Bank Muamalat Indonesia. Review of Islamic Economics, 17-29.

Karim, M., Houcem, S., Akram, T., \& Moh'd, A.-A. (2019). The Impact of Sukuk on the performace of conventional and Islamic banks. Pacific-Basin Finance Journal, 42-54.

Kassim, S., \& Majid, M. (2010). Impact of Financial Shocks on Islamic Banks: Malaysian Evidence during 1997 and 2007 Financial Crises. International Journal of Islamic and Middle Eastern Finance and Management, 291-305.

Khoutem, D. B. (2014). Islamic banks-Sukuk markets relationships and economic development: The case of the Tunisian post-revolution economy. Journal of Islamic Accounting and Business Research, 47-60.

Mahomed, Z., Ramadilli, S., \& Ariff, M. (2018). Sukuk announcement effects during financial crisis: the case for Indonesia. Journal of Islamic Accounting and Business Research, 567-686.

McMillen, M. (2007). Contractual enforceability issues: Sukuk and capital market development. Chicago Journal of International Law, 427-467.

Smaoui, H., \& Nechi, S. (2017). Does sukuk market development spur economic growth? Research in International Business and Finance, 136-147.

Sufian, F. (2010). Does Foreign Presence Foster Islamic Banks' Performance? Empirical Evidence From Malaysia. Journal of Islamic Accounting and Business Research, $128-147$.

Sugiyono. (2012). Business Research Methods (quantitative, qualitative, and $R \& D$ approaches). Bandung: Alfabeta.

Usmani, M. (2007). Sukuk and their contemporary applications, Translated from the original Arabic by Sheikh Yusuf Tala DeLorenzo. Saudi Arabia: AAOIFI Shari'a Council meeting.

Zarrouk, H., Jedidia, K. B., \& Moualhi, M. (2016). Is Islamic bank profitability driven by same forces as conventional banks? International Journal of Islamic and Middle Eastern Finance and Management, 46-66. 